\title{
Stylistic approaches of literary translation
}

\section{Shukhrat MULADJANOV ${ }^{1}$ Tozagul NASRULLAYEVA ${ }^{2}$}

Samarkand State Institute of Foreign Languages

\begin{tabular}{l} 
ARTICLE INFO \\
\hline Article history: \\
Received February 2021 \\
Received in revised form \\
20 February 2021 \\
Accepted 15 March 2021 \\
Available online \\
15 April 2021 \\
\hline
\end{tabular}

\section{Keywords:}

stylistic approaches,

extra-linguistics,

culture-specific words,

national color,

phraseological words,

linguacultural words,

socio-linguistic approach.

\begin{abstract}
This paper is devoted to stylistic approaches of literary translation rendered in extra-linguistic approaches. The peculiarities of origin text, the author's style and expressions, stylistic approaches of the text include the transmission to target language. The translator's attitude towards the cultural-bound stylistic units of the source literary text and their translation to target language. The preservation of linguacultural, phraseological and socio-cultural words from one language to another according to translation rules.
\end{abstract}

2181-1415/C 2021 in Science LLC.

This is an open access article under the Attribution 4.0 International (CC BY 4.0) license (https://creativecommons.org/licenses/by/4.0/deed.ru)

\section{Badiiy tarjimada uslubiy yondashuvlar}

\footnotetext{
Kalit so'zlar:

uslubiy yondashuvlar, ekstra-lingvistika, madaniyatga bog'liq so'zlar, milliy kolorit, frazeologizmlar, lingvomadaniy so'zlar, ijtimoiy-lingvistik yondashuvlar.
}

\begin{abstract}
ANNOTATSIYA
Ushbu maqola badiiy tarjimada uslubiy yondashuvlarning o'zaro ekstra-lingvistik yondashuvlar bilan aloqadorligiga bag'ishlangan. Matndagi asliyat - xususiyatlar, muallif uslubi va ifodasi, uslubiy yondashuvlarning tarjima tilida berilishidir. Tarjimonning asliyatdagi uslubiy birliklarning madaniy bog'likligini tarjima tilidagi yondashuvi ko'rsatilgan. Lingvomadaniy, frazeologik va ijtimoiy-madaniy so'zlarning tarjima qoidalariga ko'ra bir tildan ikkinchi tilga saqlangan holda uzatilishi yoritilgan.
\end{abstract}

\footnotetext{
${ }_{1}^{1}$ Master student, Department of Translation theory and practice, Samarkand State Institute of Foreign Languages, Samarkand, Uzbekistan. E-mail: shoxa55@mail.ru.

2 Senior lecturer, Department of Translation theory and practice, Samarkand State Institute of Foreign Languages, Samarkand, Uzbekistan.
} 


\section{Стилистические подходы литературного перевода}

\author{
Ключевые слова: \\ стилистические подходы, \\ экстра-лингвистика, \\ оснащенные культурные \\ слова, \\ национальный колорит, \\ фразеологизмы, \\ языко-культурные слова, \\ социо-языковые подходы.
}

\begin{abstract}
АННОТАЦИЯ
Эта работа посвящается стилистическому подходу литературного перевода, связанная с экстра-языковыми подходами. Особенности оригинального текста в стиле и выражении автора, стилистические подходы текста на переводимый язык. Отношение переводчика стилистическим единицам связаны с культурой в тексте оригинала и его перевода на переводимый язык. Сохранение языка это культурные, фразеологические и социально-культурные слова при переводе с одного языка к другому с помощью правил перевода.
\end{abstract}

\section{INTRODUCTION}

The co-relation of stylistic units along with the extra-linguistic approaches can be occured in the context through the national color and cultural-specific words that are peculiared to the origin language. Every stylistic devices and expressive means can be formed in a base of linguacultural, phraseological and socio-cultural words which specify the national features of source literary text. Referring to the background knowledge the translator has to convey the meaning of culture-specific words, preserving their usages into target language. The translator pays an attention how to transmit these stylistically bounded words, whether preserving the stylistic or rather an extra-linguistic patterns. But, the translation process refers to the second one through the first which is necessary for recipients to understand the national color. In this case, the stylistic units play a role of mediator in the expression of subsequent cultural words.

\section{METHODS AND MATERIALS}

The Stylistic discourse is included the multi-functionality of the usages of the stylistic devices and expressive means in order to create the emotionality of the context in literary texts. The author's style, that has been already existed in the literal prose can be determined through the chosen stylistic properties of a language. As E. Black mentioned: "It is to be expected that literary discourse will differ from ordinary conversation and some written discourse since any published work is subject to a process of careful composition and much revision" [1: P. 3]. Accordingly, the author conveys those emotions in the context by evaluating the stylistic approaches of the utterances which can be held through the extra-linguistic proposals of the source language. Thus, the translation process demands a lot of efforts to preserve those semantic uniqueness, while the work is transmitting from source language into target language. In most cases, the extra-linguistic approaches of the origin language may lead to confusion for translators, therefore, the professional translators should be aware of these patterns during the translation of literary texts, preserving the author's style, the meaning of stylistic devices and expressive means and conveying them to the target language recipients for the accurate understandings. The peculiarities of literary texts are based on stylistical majority and richness of the word combinations, which include the national color, traditions and customs, ways of communication, culture and social behalfness. In this situation, the stylistics of the literary prose deals with other disciplines, such as linguaculturology, phraseology and 
sociolinguistics, in which the root of stylistic units are founded in an essence of national features of a certain nations in a specific period of time. As for literary translators, it gives the great challenges to them, how to act during the translation of stylistic units, though they depend on extra-linguistic characteristics of a source language. Because, mainly the stylistic approaches of a literary text are an act of communication that appeared in a specific language, whereby the objective of the study of the following above mentioned disciplines. As for J.C. Catford": Language is a type of patterned human behavior, it is a way, perhaps the most important way, in which human beings interact in social situation" [2: P. 1]. Accordingly, the solution reflects also the pragmatical points of translation where the lexical units are highly studied. While the translation process is being carried, the translators should not put in direct translation of stylistic devices and expressive means, as they may lead subsequently for the wrong perception of recipients. So, the translators' attitude towards the transmission of these stylistic devices and expressive means expresses through the background knowledges of translators related to the national features of the original language. The translation's goal is aimed for identification of national uniqueness of the source language into the target language and the ways of conveying them. Lack of understanding and poor translation can lead to misunderstanding and cultural errors in a transmission of national phenomena. Basically, any of stylistic units can be deeply related with cultural phenomenon of original language that occured in a culture of certain nations. Such kind of stylistic units may be evaluated in an effect of cultural words, phraseological and socio-cultural patterns. As a reason, a translator comes across several approaches during the translation, whether to preserve the semantic meaning of culture-specific words in a context or the usages of stylistic devices. In this case, subsequently the translator uses the methods and ways to translate them from the source language into the target language:

1) Linguacultural words in a base of stylistic units can be done through the lexical and grammatical transformations.

2) Phraseological words in a base of stylistic units follow the "equivalency" methods, as a complete equivalency where the units of both languages are equal semantically and structurally, a partial equivalency refers the identity of some structures within context, that are semantically close to each other, a zero equivalency that is completely unequal languages' units. The translator has the choice out of equivalent bounded translation methods that form according to the target language norms both linguistically and extralinguistically.

3) Socio-cultural words in a base of stylistic units refers the lexical and grammatical transformations.

\section{RESULTS AND DISCUSSIONS}

1) Stylistically bounded linguacultural words are mainly relevant with the cultural and traditional habits of native people which are peculiar to source language. Target language recipients may not obtain the perception of these linguacultural words directly in their own language. Therefore, the translator plays a great role to convey such kind of word combinations to the recipients. Overall, the translator tries to use methods, that can collaborate the relevance between two languages. The main goal of translational process in this occasion is preserving the meaning of linguacultural specific words in a base of stylistic units. For example: 
Sotiboldi kasalni o'qitdi-bo'Imadi, tabibga ko'rsatdi [4: P. 8].

Sotiboldi made a local procedures-useless, then attended the doctor.

In this sentence "Sotiboldi kasalni o'qitdi" expressed through the metonymy bounded with linguacultural words of Uzbek people. This expression uses only in Uzbek nation's culture and can be unfamiliar for the target language recipients. The aim of translator is to convey this stylistic unit. The translation can not be done words for words, as it may lead to misunderstandings, so far it does not exist in translating language. The translator establishes the descriptive method, as this metonymy describes the local culture of Uzbek people. In this case, the meaning of the content is conveyed through the word combinations "made a local procedures". Another example can be seen also:

Kelinning ko'rpa-to'shak matolari bilan paxta keldi [5: P. 5].

Cotton with quilts and mattresses was brought to bride's family.

"Paxta keldi" metonymical stylistic device expressed through the passive voice structure "Cotton was brought" in translation to target language.

Unsin uyiga kirdi, paranji-chimmatini yopindi [4: P. 20].

Unsin entered the house, covered with paranji.

The linguacultural word "paranji" preserved as a realia in a translation through the lexical transformation units. The translator uses the transliteration, but he may also define it by description giving the definition of this realia in translating language.

2) Phraseological compound sentences are rendered in the literary prose, occurred in the base of stylistic units are the real challenge for translator. As for phraseology, most of phraseological words and idioms are cross-referented with stylistic devices and expressive means. Therefore, "Phraseology is a mode of figuration and a cognitive linguistic approach to figurative language is a tool that helps to perceive, understand and appreciate stylistic use of phraseological units and draw references" [3: P. 10]. In literary translation it gives some difficulties to translate them though the phraseological words do not obey to any content of the context. Thus, the translator uses the equivalent methods for preserving the phraseological meaning of idioms and phraseological words. Complete, partial and zero equivalency methods may evaluate the meaning of phraseological words in translation. During the transmission the translator's purpose is to preserve the phraseological meaning rather than stylistic units. The following examples can be regarded as the evidences to the theory:

Mana shunday vaqtlarda til qotib og'izda aylanmay qoladi [4: P. 14].

This time one cannot speak, biting the tongue.

"Can not speak, biting the tongue" is determined as partial equivalent to the source language "til qotib og'izda aylanmay qoldi".

Turobjonning tepa sochi tikka bo Idi [4: P. 15].

Turobjon have batted the eyelid.

Dodxoning dami ichiga tushib ketdi [4: P. 19].

Dodkho was beyond the speech.

Both sentences are related to zero equivalency methods, which the phraseological units of origin language are adapted to the target language's phraseological units. Here, the translator defines only the equivalents in target language. "Tepa sochi tikka bo'ldi" "Batted the eyelid" and "Dami ichiga tushib ketdi" - "To be beyond the speech" are familiar to their own speakers. 
3) Socio-linguistic approaches of stylistics are basically relevant to the social communication of native speakers. Most of local words of a certain nation are unfamiliar in the foreign language, as they regarded poly-semantic words in a root of social aspects of linguistics. Thus, the multi-functionality of these kind of words are rendered in an approach of stylistic usages. While stylistically used words may confirm indirect meaning in the passage, as they appeared in the inter-communication of social group of people or community. In translation of those socio relevant words, apparently advised to use the equivalent sufficient or close words or word combinations. So, the words in origin can be omitted, replaced or developed through the substitutions in translating language. For example:

Hoji birpas zaharini yutib turdi [4: P. 23].

Hoji stayed a bit anxiously.

"Zaharini yutib turdi" is a metonymy that involves the word "zahar" in its indirect meaning, as appeared in the communication of social group of people. In this phrase the word "zahar" is not used in its own lexical meaning. It denotes the condition of a person in a context. So, there is no any substitution to the word "zahar" in target language and the translation states only with the statement of a person. Same comparisons may be seen in the following examples:

Xo'p, lafzimdan qaytmayman, mana xotirjam bo'la qol [4: P. 19].

All right! I keep my words, be relaxed.

Jigarlaring ezilib kestin [4: P. 16].

Let your dearest be disappeared.

Tildan qoldingmi? [4: P. 19].

Are you mute?

The understanding of the literary text depends on knowledge of the culture of the people in whose language a literary work was created. The sociocultural way of life of a certain national community is reflected in vocabulary and constitute background information in it, transforming information about national features of spiritual and material culture. Preserving the translation of national color of the source units depends on the correct perception of the background information. The aim of translation is not to convey the text to one's perception, but to preserve the content, style, stylistic, communicative and literary values of the original.

\section{CONCLUSION}

The stylistic approaches of literary translation value with their extra-linguistic effects in the original context. The translator should be aware of these extra-linguistic approaches while translating the stylistic devices and expressive means, because most of them are related to each other. In this case, the translator's background knowledges must be also available to transform these units. It has to be mentioned that national features and color of origin should be preserved, in order to convey to target language recipients. And the stylistic devices may play a role of mediator to express these cultural-bounded extralinguistic units. In this situation, the most important challenge is the proficiency of a translator to find out an adequate translation that may contribute the perception of origin text into target language by the recipients. 


\section{REFERENCES:}

1. Black, E. (2005). Pragmatic stylistics. Edinburgh University Press.

2. Catford J.C. (1978). A linguistic theory of translation. Oxford University Press.

3. Naciscione A (2010). Stylistic use of phraseological units in discourse. John Benjamins Publishing Company. lami.pdf.

4. http://ziyouz.com/books/uzbeknasri/Abdulla\%20Qahhor\%20Dahshat\%20to'p

5. http://n.ziyouz.com/books/nasri/Tog'ay\%20Murod\%200ydinda\%20yurgan\% 20odamlar\%20(qissa).pdf. 